\title{
Editor's Introduction to v40(1)
}

\author{
Harriet Hartman ${ }^{1}$
}

Published online: 26 May 2020

(c) Springer Nature B.V. 2020

Oh my. What strange times we are experiencing. The curse and the promise of living in "interesting times."

This issue begins on a somber tone. Two of our editorial board members passed away recently, Menachem Friedman prior to the coronavirus pandemic, and William Helmreich as a result of the virus. Their contributions to the social scientific study of Jewry, and to their own social and professional worlds, have been great, and they are each sorely missed. Each is remembered in a memorial in their honor. May their memories be for blessings.

The scholarly part of this volume is a special issue on "Judaism and World Religions", which itself is somewhat of an unusual presentation for Contemporary Jewry, both in terms of its subject matter and in terms of its presentation. Guestedited by Rabbi Dr. Alon Goshen-Gottstein, founder of the Elijah Interfaith Institute in Jerusalem, this special issue grew out of a series of sessions at the World Congress of Jewish Studies held in Jerusalem in 2017. The sessions' common title, "Judaism and World Religions", caught my eye. I realized that most of the publications in Contemporary Jewry dealt with Jews in the contemporary world, but few grappled with a reality that is increasingly relevant both in Israel and in the Diaspora-the relationship of the religion of Judaism to other world religions. A fair number of our publications deal with the Jewish people (collectively or in small groups) in relation to non-Jewish people in terms, for example, of family (interfaith marriages), politics (antisemitism), or economy (Jewish occupations in relation to the broader labor force, or charitable donations to Jewish and non-Jewish causes). But the few articles we have published on religion per se focus on the Jewish religion, rather than the relationship between Judaism and other religions. Perhaps that is natural in a journal devoted to the social science of contemporary Jewry. But religion and its components-including meaning-making, and not just its communal belonging or structural aspects-are an important part of the cultural foundations of any civilization. The sociology of religion understands that the actual beliefs of a religion are foundational to its this-worldly structure, rituals, and lifestyles. Ontological beliefs provide justifications and legitimations of particular social structures

Harriet Hartman

Hartman@rowan.edu

1 Glassboro, USA 
and collective - as well as individual — goals, which constitute the this-worldly pursuits that are valued. Ontological foundations also put up barriers to cross-cultural understanding, respect, civil discourse, and cooperation. They also underscore the value placed on religious actors, and their relative influence and credulity within the structure of any particular society's power dynamics. While Jews are acutely aware of the role of religious "nones" in Western societies and among Jews in particular, the Jewish religion still underlies many of the value choices among Jewish people and their activities, and the organized face of Jews is often/usually affiliated with Jewish religion. While secularization has spread among Western civilization, so has increased religiosity, so much so that no prediction of the demise of religion has proven accurate, not within Western societies, and certainly not globally.

It is with this mindset that I was intrigued with the possibilities of bringing to our readership a dialogue between Judaism and world religions, often in terms of religious concepts and tenets, but also related to religious leadership, and the social and historical contexts out of which different religions developed (and persist). Again, we are somewhat familiar with this line of thought in terms of exploring how Judaism is shaped by its many and varied diaspora settings in comparison to Israel, and how the practice of Judaism may change as Jewish immigrants establish themselves in a new society from one generation to the next. But we are somewhat less familiar with the idea of the Jewish religion itself in dialogue with other religions.

Not only does this special issue open up this new direction of thought for our readers, it is also structured somewhat differently than the type of research we usually present. Each essay is a hybrid of a book review and critical analysis, something social scientists regularly engage in in terms of a literature review which situates their own research in a field and the way it expands or corrects past work. Such work is an integral part of social science research both in terms of setting the stage for data collection and, most importantly, for its interpretation. In this case, the data is the body of work produced by Goshen-Gottstein and his Institute, and the ways they are used to inform the theoretical innovation of Goshen-Gottstein's endeavors.

The structure of the special issue is therefore based on the collected works of Goshen-Gottstein, alone and in collaboration with scholars who have participated in the conversations, conferences, publications, and events sponsored by the Elijah Interfaith Institute. The session at the World Congress of Jewish Studies presented critical reflections on a number of these volumes and the concepts they focus on. And so follows the structure of this special issue. Each essay focuses on a particular body of work that has been published, reviews it, and enters into a critical dialogue with its theses, critically discussing its importance, its limitations, and its implications for the future.

In the first essay, Alon Goshen-Gottstein introduces us to his work and the essays to follow. Goshen-Gottstein suggests that religions do not develop in vacuums, but rather in dialogue with their environments and the other religions which surround them-whether consciously or not. Recognizing this reality, one that is consonant with the necessity of contextualizing any social phenomena, should resonate with social scientists. Goshen-Gottstein takes this to the realm of theology, the meaning-making system of religion itself. He suggests that religions must internalize the pluralistic nature of our social reality and make their dialogues with the external a 
conscious part of their internal dynamics, so that a richer coevolution of religions individually and religion collectively takes place.

Subjects that are covered in the following papers include such topics as the nature of religious leadership, the concept of the religious "Other," the concept of avodah zarah (idol-worship), and the promotion of dialogical theology. Each essay provides a particular angle on contemporary Jewry either by viewing the possibilities that are opened up through dialogue and engagement, or by appreciating its particularity within the broader comparative framework of some of the work surveyed.

In an increasingly global world, something that has been made clear to us from the very global pandemic we are living through, it is critical that cultures and religions be able to engage each other with mutual understanding and respect, in order to jointly tackle global challenges and collaborate toward a better shared future. Granted that the religious leadership in some parts of the world is often marginalized, in other parts of the world it is at the forefront; developing an understanding which permits respectful dialogue among religions will enable cooperative global endeavors to take place and become more effective. However, initiatives to promote such endeavors are often marginalized or hidden. In an effort to bring to your awareness the challenges in pursuing such a dialogical theological endeavor, I hope you will find the essays in this special issue provocative and inspiring.

We end this volume with our regular features of research updates and book reviews, this time in the shape of an expanded review of two recent books on the same topic, the political liberalism of American Jews, but with different perspectives.

As always, happy reading and thinking! And may you all stay safe and well. 